Portland State University

PDXScholar

$10-3-2021$

\title{
When Are the Bigger Fish in the Small Pond Better Citizens? A Multilevel Examination of Relative Overqualification in Workgroups
}

\author{
Farid Jahantab \\ Pennsylvania State University \\ Prajya R. Vidyarthi \\ University of Texas at El Paso \\ Smriti Anand \\ Illinois Institute of Technology \\ Berrin Erdogan \\ Portland State University, berrine@pdx.edu
}

Follow this and additional works at: https://pdxscholar.library.pdx.edu/busadmin_fac

Part of the Business Commons

Let us know how access to this document benefits you.

\section{Citation Details}

Jahantab, F., Vidyarthi, P. R., Anand, S., \& Erdogan, B. (2021). When Are the Bigger Fish in the Small Pond Better Citizens? A Multilevel Examination of Relative Overqualification in Workgroups. Group \& Organization Management, 105960112110480. https://doi.org/10.1177/10596011211048055

This Post-Print is brought to you for free and open access. It has been accepted for inclusion in Business Faculty Publications and Presentations by an authorized administrator of PDXScholar. Please contact us if we can make this document more accessible: pdxscholar@pdx.edu. 


\title{
When Are the Bigger Fish in the Small Pond Better Citizens? A Multi-Level Examination of Relative Overqualification and Outcomes in Workgroups
}

\author{
Farid Jahantab \\ Department of Marketing and Management \\ College of Business Administration \\ The University of Texas at El Paso \\ $500 \mathrm{~W}$ University Avenue \\ El Paso, Texas 79968, USA \\ fjahantab@utep.edu \\ (816) 617-1246 \\ Prajya R. Vidyarthi \\ College of Business Administration \\ The University of Texas at El Paso \\ $500 \mathrm{~W}$ University Avenue \\ El Paso, Texas 79968, USA \\ prvidyarthi@utep.edu \\ (915) 747-5380 \\ Smriti Anand \\ Stuart School of Business \\ Illinois Institute of Technology \\ 10 West 35 th Street \\ Chicago, Illinois 60616, USA \\ sanand12@stuart.iit.edu \\ (312) 906-6583 \\ Berrin Erdogan \\ The School of Business \\ Portland State University \\ 1825 SW Broadway \\ Portland, Oregon 97201, USA \\ berrine@pdx.edu \\ (503) 725-3798
}




\begin{abstract}
In this study, we extend overqualification research to employees' social context of workgroup membership. Drawing upon social comparison theory and integrating with social exchange theory, we contend that employees' relative overqualification (ROQ; defined as individual overqualification relative to other group members' overqualification perceptions) is associated with their relative standing with their leader (measured as LMXSC: leader-member exchange social comparison), which in turn relates to employees' organizational citizenship behaviors (OCB). Furthermore, we assert that workgroup structural attributes and individual values (leader span of control and power distance orientation) influence the ROQ-LMXSC-OCB relationship. Multi-level modeling using data from 243 employees nested in 36 workgroups suggested patterns of moderated mediation where leader span of control and employee power distance orientation moderate the indirect link between ROQ and OCB through LMXSC. That is, the indirect relationship between ROQ and OCB is stronger in workgroups with a narrow leader span of control and for employees high in power distance orientation. Implications and directions for meso- and group-level research are discussed.
\end{abstract}

Keywords: overqualification, leader-member exchange social comparison (LMXSC), power distance, span of control, organizational citizenship behaviors (OCB) 
At any given time, employees may feel that they are working in positions that neither require nor utilize their qualifications such as education, experience, skills, and abilities (Johnson \& Johnson, 1996; Johnson, Morrow, \& Johnson, 2002). Scholars define overqualification as an occupational mismatch whereby individuals have surplus education and lack opportunities for using and enhancing their skills (Johnson \& Johnson, 2000). According to a 2014 study by the nonprofit Urban Institute, about $25 \%$ of U.S. college graduates were overqualified for their jobs (Rose, 2017). Similarly, a European study found that half of its sample of higher education graduates was either overeducated or employed outside their fields of study (Allen \& van der Velden, 2001). The rate of overqualification is even higher among immigrants, as Chen, Smith, and Mustard (2010) reported that over 50\% of Canadian immigrants were overqualified for their jobs. The persistently high rate of overqualification is a cause for concern given the pervasive negative outcomes associated with overqualified employees. A meta-analysis of the literature indicates that it is related to poor job attitudes, higher turnover rate, and greater levels of counterproductive work behaviors (Harari, Manapragada, \& Viswesvaran, 2017), leading the authors to conclude that "understanding the psychological experience of working in a job for which one is overqualified has become a central concern in the literature" (p. 28). We therefore aim to understand how overqualification relates to employees' psychological experiences and work outcomes in teams.

Most research into overqualification has examined this phenomenon as one experienced by an individual employee (Lin, Law, \& Zhou, 2017; Zhang, Law, \& Lin, 2016); however, we argue that employees do not assess and react to their overqualification in a vacuum. Employee evaluations of overqualification occur in the social setting provided by the workgroups, wherein comparisons with coworkers are commonplace, making it critical to focus on employees' 
overqualification relative to workgroup members' overqualification. In other words, we suggest that employees' experience of overqualification also depends on their qualifications relative to others in the workgroup and that relative overqualification has unique implications for employees' psychological responses and behavior beyond those of perceived overqualification. Our conceptualization is aligned with Erdogan and colleagues' (Erdogan, Bauer, Peiró, \& Truxillo, 2011) theorizing that employee reactions to overqualification are likely to be shaped by group members' experience with overqualification, and the prevalence or rarity of overqualification within the workgroup (also see Liu \& Wang, 2012). We, therefore, draw on social comparison theory to introduce the concept of relative overqualification (ROQ), which we define as a focal employee's perceived overqualification relative to the average level of overqualification perceived by coworkers in the workgroup. High ROQ means that a focal employee perceives himself/herself to be more overqualified than the workgroup average perception, and low ROQ indicates that a focal employee perceives himself/herself to be less overqualified than the workgroup average perception. By conceptualizing overqualification at the individual-within-a-group or meso level, we address the possibility that in any given workgroup employees who feel overqualified may be surrounded by others with similar or dissimilar feelings, and that has implications for employee attitudes and behaviors. We explore employee perceptions of overqualification driven by within-group social comparison processes to advance knowledge in overqualification research.

Our study makes three important contributions to the literature. First, building on tenets of social comparison theory we seek to conceptualize overqualification at the individual-withina-group level (Klein, Dansereau, \& Hall, 1994; Kozlowski \& Klein, 2000) and identify its correlates. We theorize that because employees are embedded in workgroups and social 
comparison processes are inseparable elements of human nature (Wood, 1989), employee overqualification needs to be examined relative to other workgroup members' overqualification. We investigate how the perceptions of overqualification relative to the group driven by withingroup social comparison processes explain unique variability in employee behavior left unexplained by individual-level perceptions of overqualification. Though many studies have examined the relationship between perceived overqualification and employee behaviors (e.g., Deng et al., 2018; Erdogan, Karaeminogullari, Bauer, \& Ellis, 2020), to date, only one study (Hu et al., 2015) has examined the outcomes of a focal employee's perceived overqualification while accounting for the workgroup context. Specifically, these scholars found that for employees who feel overqualified, working with similarly overqualified peers resulted in greater attraction to peers. However, Hu et al.'s study did not explain employee-manager relationships. Unlike coworker relations where similar levels of perceived overqualification may predict attraction, employee-manager relations may benefit from the employee's greater overqualification relative to coworkers. Therefore, our study makes a unique contribution by building on Hu et al. (2015) and examining relational standing with one's leader in relation to ROQ. We integrate social comparison theory (Festinger, 1954) with social exchange theory (Blau, 1964) to suggest that employees' standing in the workgroup overqualification distribution relates to the way they assess their relationship quality with the leader in comparison to coworkers' relationships (i.e., LMXSC: relative LMX standing in the group), beyond the effects of perceived overqualification. Second, we seek to identify theoretical underpinnings at the meso level to link ROQ to citizenship behaviors. In doing so, we emphasize social exchanges that take place among workgroup members and capture the social comparison processes that emerge within the social context of workgroup settings to link ROQ to employees' actual behaviors. We draw on leader- 
member exchange literature to suggest that ROQ is positively associated with OCB because relatively overqualified workers are likely to experience a higher quality relationship with their leader compared to their coworkers, and reciprocate the positive treatment in the form of citizenship behaviors. Thus, we contribute to leadership literature by introducing an important predictor of LMX social comparison. Although there is a large literature examining the outcomes of LMX (Dulebohn, Bommer, Liden, Brouer, \& Ferris, 2012), studies investigating the factors that can explain employee perceptions of their relative standing with the leader are rare.

Finally, we strive to contextualize overqualification literature by investigating the interplay of within-group social comparison of overqualification with within-group differences arising from individual power distance orientations and between-group differences in leader's span of control. In so doing, we address scholars' call for investigating the context of overqualification (Harari et al., 2017). Leadership scholars maintain that the quality of a leaderfollower relationship depends on individual member and workgroup attributes (Anand, $\mathrm{Hu}$, Liden, \& Vidyarthi, 2011; Dulebohn et al., 2012). We chose leader's span of control and employee power distance orientation as exemplars of structural context and individual normative attributes surrounding the ROQ-LMXSC-OCB relationship. This is because past research suggests that an increase in leader span of control makes followers perceive fewer opportunities for relationship development (Henderson, Liden, Glibkowski, \& Chaudhry, 2009), whereas employees with high power distance orientation value leader's power (Erdogan \& Liden, 2002), motivating them to work towards improving the dyadic relationship quality. Our choice of group context and individual attribute is also supported by Margolis and Dust's (2019) notion that individual characteristics and group factors both affect within-group social comparison processes (e.g., employee assessments of LMXSC). We suggest that the leader's span of control and 
employee's power distance orientation will act as moderators such that the positive association between ROQ and employees' perceived LMX standing are more likely to emerge when leaders have greater interaction opportunities with workgroup members (narrow span of control), and when employees embrace unequal distribution of power (high power distance orientation). Our research model is shown in Figure 1.

\section{Theory and Hypotheses}

\section{Relative Overqualification, LMX Social Comparison, and OCBs}

Overqualification has been conceptualized as both perceptual and objective. Perceived overqualification refers to the extent to which employees consider themselves as having more education, talent, experience, and/or skills than required by their jobs (Johnson \& Johnson, 1996; Johnson et al., 2002), and the construct aims to assess the perceptual mismatch between an employee's knowledge, skills, and abilities (KSAs), and the job requirements (i.e., demandsabilities fit). On the other hand, objective overqualification is the actual difference between individual qualifications and job requirements (Hu et al., 2015; Maltarich, Reilly, \& Nyberg, 2011). Perceived overqualification is conceptually distinct from objective overqualification because researchers have proposed differential nomological networks for them (Erdogan et al., 2011). Furthermore, perceived overqualification and objective overqualification are only moderately correlated $(\rho=.40$ : Harari et al., 2017). As such, while these two constructs are associated, they are also distinct. Scholars maintain that perceived overqualification is a more proximal determinant of employee reactions compared to objective overqualification (Lin et al., 2017; Maynard \& Parfyonova, 2013) because perceptions are more powerful than the objective reality (Kristof-Brown, Zimmerman, \& Johnson, 2005) in predicting behaviors. Furthermore, even jobs with the same titles vary so much in their content and dimensions that objective 
overqualification fails to capture these differences (Maltarich et al., 2011), rendering perceived overqualification more attractive and appropriate for understanding employee reactions. Therefore, we focused on employee perceptions of overqualification rather than the objective difference between their qualification and the job requirement (i.e., objective overqualification).

Perceived overqualification has largely been studied as a phenomenon experienced by an individual employee (Erdogan \& Bauer, 2009); however, we argue that employees are less likely to experience overqualification in isolation. Organizations worldwide are designing work that requires collaboration with coworkers (Hackman, 2002; Morgeson, DeRue, \& Karam, 2010), so within-group social comparisons are pivotal to how individual employees perceive and react to their overqualification. Our assertion draws on social comparison theory (Buunk \& Gibbons, 2007; Festinger, 1954), which suggests that human beings have a natural tendency to evaluate their standing relative to others, and these subjective assessments of relative social stature influence individuals' attitudes, aspirations, and behaviors (Wood, 1989; 1996). Social comparisons occur spontaneously and effortlessly (Gilbert, Giesler, \& Morris, 1995) prompting employees to constantly scan their environments seeking information to help them form comparative judgments that shape reactions to their own circumstances. Employees engage in observation, conversations, and interactions with peers (Wood, 1996) to gather information about coworkers for these social comparisons. Indeed, scholars note that employees tend to notice when a colleague has different abilities and attributes (Greenberg, Ashton-James, \& Ashkanasy, 2007). We, therefore, contend that because employees are intrinsically embedded in workgroups and social comparisons are innate to human nature (Wood, 1989), employees evaluate their overqualification by comparing to their close referents - coworkers (Ho, 2005). Such social comparisons are likely to influence employees' perceived overqualification as well as their 
relative overqualification, which situates this overqualification perception relative to the group.

We conceptualize relative overqualification (ROQ) as an individual's perceived overqualification relative to the average level of overqualification in the workgroup as perceived by one's coworkers.

The role of peer overqualification in shaping the outcomes of focal employee perceived overqualification has been recognized by scholars. Hu and colleagues (2015) found that the positive relationship between employee perceived overqualification and group identification was stronger when peer-reported overqualification was high. Extending this work, we assert that ROQ has implications for Leader-Member Exchange Social Comparisons (i.e., LMXSC: Vidyarthi, Liden, Anand, Erdogan, \& Ghosh, 2010). LMXSC refers to the subjective ratings by individuals of their LMX compared to the LMXs of coworkers. Researchers distinguish LMXSC from LMX in that "LMXSC is based on within-group social comparison with workgroup members as the reference point, whereas LMX involves no comparative judgment or reference point" (Vidyarthi et al., 2010, p. 850). Following our theoretical conceptualization of overqualification based on social comparison theory (i.e., ROQ), we are interested in viewing the employment relationship of the focal employees relative to others in the workgroup. Thus, to theorize and conceptualize ROQ and its effect we focus on LMXSC rather than LMX, as ROQ is a proxy to capture social comparison and so is LMXSC.

We assert that employees who feel more overqualified than others in the workgroup likely perceive a higher quality relationship with the leader than do their less overqualified counterparts. Our assertion draws on leader-member exchange literature, which shows that capable employees enjoy higher social status (Martin, Guillaume, Thomas, Lee, \& Epitropaki, 2016), closeness (Harris, Li, \& Kirkman, 2014), and perceived similarity (Dulebohn et al., 2012) 
with their leaders, and LMXs based on employee performance have more positive implications for groups (Han, Liao, Han, \& Li, in press). In addition, employees with high ROQ may believe that they are overskilled and underutilized in comparison to their coworkers. High relatively overqualified employees thus may feel their surplus qualifications are resources to share with their leader. LMX theory (Dienesch \& Liden, 1986) suggests that leader-follower relationship quality may develop and sustain differently based on the types of resources being exchanged in the dyad. Leaders may then construe employee overqualification as a resource, and find relatively overqualified employees as individuals who can be counted on, trusted, and sought help from. Therefore, we expect ROQ (i.e., higher than within-group average overqualification perceptions) to have a positive effect on one's relative standing with the leader.

Further, emphasizing the social exchanges that take place among workgroup members, we contend that ROQ indirectly relates to employees' organizational citizenship via their perceptions of LMXSC. Organizational citizenship behaviors (OCB) refer to the employees' discretionary efforts that contribute to the organizational well-being (Williams \& Anderson, 1991). Drawing upon social exchange theory (Blau, 1964), we postulate that overqualification is a valuable resource that motivates higher quality leader-employee relationships. Furthermore, drawing on the norm of reciprocity (Gouldner, 1960), we contend that the valuable and limited relational resources inherent in LMXSC are likely to be reciprocated by employees. When employees believe that their leader has a closer professional relationship with them than with other workgroup members, they feel obligated to reciprocate their leader's favor (Cropanzano \& Mitchell, 2005). In other words, high relatively overqualified employees will engage in more citizenship behaviors because they perceive a better relationship with their leader when they compare their standing with that of coworkers' standing and feel obligated to give back the 
positive treatment that they received from their leader. On the other hand, low relatively overqualified employees will engage in lower levels of citizenship behaviors as they do not perceive a better relationship with their leader and feel less obligated to return any relational favor that they received from their leader. As a result, we propose that the indirect relationship between ROQ and OCB transpires through LMXSC.

Hypothesis 1: ROQ is positively associated with LMXSC.

Hypothesis 2: LMXSC mediates the relationship between $R O Q$ and $O C B$.

Workgroups are "breeding grounds for social comparison” (Margolis \& Dust, 2019, p. 375) such that the ROQ-OCB relationship hinges on employees' social comparison-based assessments of their relative LMX standing with the group leader. The leader is the authority figure in the workgroup who assigns tasks and grants resources to meet one's goals (Graen, 1976; Sparrowe \& Liden, 1997). Thus, it makes sense that group members value their relationship with the leader, and keep track of how their colleagues are doing in that respect (Vidyarthi et al., 2010). Leader-member exchange literature suggests that these comparisons between teammates regarding their relative standing with the leader are affected by both individual and group attributes (Hu \& Liden, 2013; Vidyarthi et al., 2016). In fact, members of workgroups operate within the context of both group and self (Smith \& Berg, 1987) - the effects of individual and group attributes may at times be complementary and competing at others (Watson, Johnson, \& Merritt, 1998), and thus a joint examination of both is needed to understand ROQ-LMXSC-OCB relationship in workgroups. Therefore, we incorporate individual- and group-level variables into overqualification research and propose that group structural attribute of the leader's span of control, and individual normative attribute of power distance orientation will moderate the mesolevel ROQ-LMXSC-OCB relationship. We chose these two specific moderators because the span 
of control and power distance orientation influence the development of LMXSC from the leader's and the follower's perspective respectively. Span of control reflects the leader's capacity to invest in the relationship, whereas power distance orientation reflects the follower's orientation towards the leader and the extent to which they will invest in the success of their leader.

\section{The Moderating Role of Leader's Span of Control}

The leader's span of control is defined as the total number of subordinates over whom a leader has responsibility, authority, and control (Blau \& Schoenherr, 1971; Simon, 1957). As a property of workgroup structure, span of control can help measure the closeness of contact between leaders and their subordinates (Ouchi \& Dowling, 1974). Previous research has suggested that a wide span of control increases cost efficiency, but reduces the positive effects of effective leadership styles (Meyer et al., 2011). In light of social comparison theory, we expect the leader's span of control to attenuate the positive relationship between ROQ and LMXSC. Wide span of control provides a leader with a relatively larger number of subordinates to choose from to develop differential quality relationships with. Under these conditions, information overload and limited cognitive capacity make it difficult for the leader to thoroughly evaluate each employee and decide what quality relationship to form and maintain with them. A wide span of control accentuates the social distance between the leader and subordinates and forces the leader to treat subordinates more homogeneously (Antonakis \& Atwater, 2002). The leader also finds it difficult to notice relatively overqualified employees due to limited opportunities for interaction.

Similarly, relatively overqualified subordinates may not expect their leaders to establish a relatively high-quality LMX with them when the span of control is wide. LMX theory maintains that the tenor of the dyadic relationship depends on both the leader and subordinate; employees 
are not passive recipients of leadership (Graen \& Scandura, 1987). In the leader-employee dyadic relationship, employees realize that the leader has more discretion in choosing relationship partners. In a wide span of control condition, the leader has many choices for highquality relationship partners, and limited interaction opportunities to evaluate each employee. These challenges are likely recognized by relatively overqualified employees when they are engaging in social comparison of their LMX quality with that of the other group members. Our assertion is aligned with leader-member exchange literature, which maintains that the number of a leader's subordinates influences the quality of subordinates' individualized relationships with their leader (Henderson et al., 2009), as forming high-quality LMX relationships requires time (Dansereau, Graen, \& Haga, 1975), effort (Maslyn \& Uhl-Bien, 2001), and resources (Liden, Sparrowe, \& Wayne, 1997) that are not limitless. Accordingly, as the number of subordinates increases, it becomes more difficult for a leader to expend the time, effort, and resources necessary to meet the unique needs of relatively overqualified employees. Therefore, we expect that a wide span of control weakens the positive relationship between ROQ and LMXSC.

Hypothesis 3: Leader's span of control weakens the positive relationship between $R O Q$ and LMXSC.

\section{The Moderating Role of Power Distance Orientation}

Power distance orientation describes the extent to which individuals accept unequal distribution of power in society. Individuals with high power distance believe that they should respect and obey those with authority and power, and adhere more to organizational hierarchy than individuals with low power distance (Hofstede, 2001). Personal and social norms (Berger, Cohen, \& Zelditch, 1972), such as power distance act as roadmaps that help people predict, explain, and reduce uncertainty about their social behavior (Reis \& Sprecher, 2009). Power 
distance is particularly relevant to leader-follower relationships because of the innate power asymmetry whereby the leader has positional, reward, and coercive power (Anand et al., 2011; Anand, Vidyarthi, \& Rolnicki, 2018; Erdogan \& Liden, 2002). We posit that employee power distance orientation may enhance the ROQ-LMXSC relationship. This is because power distance orientation deals with an individual's values in relation to status, authority, and power (Kirkman, Chen, Farh, Chen, \& Lowe, 2009). Employees with high power distance orientation obey leaders' instructions without questioning and believe that leaders are superior and elite, who deserve respect and deference and provide more reliable decisions (Javidan, Dorfman, de Luque, \& House, 2006). Such employees will likely avoid disagreements with the leader and believe that bypassing their bosses is insubordination (Hofstede, 2001).

Employees with higher power distance orientation may place greater value on authority figures. A leader is the immediate authority figure in the workgroup, and thus we expect employee power distance orientation to shape the ROQ-LMXSC relationship in that social context. We posit that high power distance employees value status differences, and thus desire and expect their leader to notice the differences of overqualification between group members when forming LMX quality. Such employees with qualifications exceeding job requirements relative to their peers (i.e., high ROQ) may feel that they should maintain a higher quality relationship with the leader who has higher status. We, therefore, expect high power distance employees with a high standing on the group overqualification distribution to put more effort in establishing a relatively higher quality LMX. In addition to leader's position, his/her resources may be a powerful motivator to expend more effort in enhancing their relative standing with the leader (Erdogan \& Liden, 2002). High relatively overqualified employees have the capability to be more effective and helpful to their leader - and if they also have high power distance 
orientation - they are less of a threat to the leader as they are more respectful of the leaders' status and inherent right to make decisions. On the other hand, low power distance orientation employees endorse norms of equality and informality (Yang, Mossholder, \& Peng, 2007), put less value on relative standing with the leader, and expend less effort towards building that. The quality of leader-follower relationships depends on efforts made by both parties (Liden, Anand, \& Vidyarthi, 2016; Maslyn \& Uhl-Bien, 2001). Leader-member exchange theory maintains that the dyadic relationship forms and evolves through the process of role taking, role making, and role routinization (Graen, 1976; Graen \& Scandura, 1987). Within the same workgroup, each leader-follower relationship may develop uniquely based on the resources exchanged, and the process of member evaluation and task delegation by the leader, and the corresponding response from the follower. At the heart of leader-member exchange theory lies processes of social exchange and reciprocity, and some of the notable currencies of exchange include respect, trust, and loyalty (Dienesch \& Liden, 1986). The leader may notice high power distance orientation and relatively overqualified employee's obedience, respect, trust (Sparrowe \& Liden, 1997), and a willingness to embrace the given role and enhance the dyadic relationship quality. The leader may then feel obligated to put more effort in such relationships. Leadermember exchange theory asserts that due to competing demands on their time and resources, leaders choose only a few followers to establish a high-quality relationship with (Graen, 1976). Hence, it makes sense for them to choose group members with high ROQ and power distance orientation, who have the capability to carry out the leader's wishes with loyalty and respect, and thus can be counted on to be the 'trusted lieutenants'.

\section{Hypothesis 4: Employees' power distance orientation strengthens the positive} relationship between $R O Q$ and $L M X S C$. 
Given the moderation hypotheses and the notion that leader span of control and employee power distance orientation affects employees' social comparison processes used to evaluate their relative LMX standing in the workgroup, we expect span of control and power distance orientation to also impact the strength of the indirect relationship between ROQ and OCB, demonstrating patterns of moderated mediation.

Hypothesis 5a: Leader's span of control moderates the indirect relationship between $R O Q$ and $O C B$ via LMXSC, such that the indirect positive relationship is stronger when leader's span of control is narrower.

Hypothesis 5b: Employees' power distance orientation moderates the indirect relationship between $R O Q$ and $O C B$ via LMXSC, such that the indirect positive relationship is when employees' power distance orientation is higher.

\section{Methods}

\section{Sample and Procedure}

Data were collected from employees working in 37 restaurants located in the Southwestern U.S. Upon receiving approval from the managers, the research team visited each restaurant to administer paper-pencil surveys. We gathered data from two different sources: employees and their leaders. All workgroup members and their leaders were asked to participate under the assurance of confidentiality. Thirty-seven leaders and 251 employees embedded in 37 workgroups participated in the study. We administered surveys in both English and Spanish due to a large number of native Spanish speakers in our sample and applied a translation-back translation procedure for the surveys in Spanish (Brislin, 1980).

Because ROQ is derived from the comparison of employee overqualification relative to the group mean, a high within-group response rate was necessary. Therefore, we restricted our 
analyses to groups where within-group response rate was over 60\% (Timmerman, 2005). In our sample, the average within-group response rate was $84 \%$. One group was excluded from the analysis because the within-group response rate fell short of the $60 \%$ cutoff. Our final usable sample consisted of 243 employees and 36 leaders nested in 36 groups. Workgroups consisted of 3 to 17 employees, and the average group size was $6.75(\mathrm{SD}=3.45)$. Average employee age was 26.13 years $(\mathrm{SD}=7.87)$, and average leader age was 35.01 years $(\mathrm{SD}=9.55)$. Employees were $62.7 \%$ female, whereas $67.9 \%$ of the leaders were male. More than half of the employees $(58.8 \%)$ had a college education (graduate or student), whereas all of the leaders had at least a 4year college degree. Average employee dyadic tenure with the corresponding supervisor was 1.71 years $(\mathrm{SD}=2.32)$, and average leader organizational tenure was 4.08 years $(\mathrm{SD}=3.67)$.

\section{Measures}

Employees reported their perceived overqualification, LMXSC, power distance orientation, and demographics. We assessed employees' OCB and span of control from their leaders' perspective. Responses to survey questions were measured on 5-point Likert-type scales ranging from 1 = strongly disagree to $5=$ strongly agree.

Perceived overqualification (POQ). We used the four-item measure by Johnson and Johnson (1996) to measure employee's perceived overqualification. Sample items are "I have more education than what my job requires," and "I have more experience than necessary to be successful in this job" $(\alpha=.86)$.

Relative overqualification (ROQ). Relative overqualification scores were derived from perceived overqualification ratings. We calculated ROQ by subtracting the group mean of overqualification from a focal employee's perceived overqualification score. We chose to use difference scores over polynomial regression following the recommendation made by Tse, 
Ashkanasy, and Dasborough (2012). First, Tse and colleagues opined that polynomial regression is preferable only when both variables are perceptual - which is not the case in our study. This is “because Edwards' (1995) original critique of difference scores dealt with the problems associated with difference scores between two perceptual variables" (p. 359). The issue raised by Edwards (1995) may be less of a concern to our study because in our study we calculated ROQ by calculating individual POQ score minus the group mean value of POQ (an algebraic estimation). Second, researchers have continued to use and operationalize difference scores as substantial and meaningful variables (e.g., Epitropaki \& Martin, 2013; Henderson et al., 2008; Tse et al., 2012; Vidyarthi et al., 2016). Third, the difference score is arguably more intuitive than the polynomial regression analyses. Furthermore, because polynomial regression requires the introduction of five new terms in the regression equation - the fact that we have two moderators makes it even more unwieldy - the difference score method is more parsimonious and appropriate for a sample of modest size. Nonetheless, we included the group mean of POQ (labeled GOQ) as a group-level variable in our analyses.

LMX social comparison (LMXSC). We used a six-item scale developed by Erdogan (2002) and first used by Vidyarthi et al. (2010) to assess LMXSC. Sample items are "I have a better relationship with my leader than most others in this restaurant," and "Compared to others in this restaurant, I receive more support from my supervisor" $(\alpha=.90)$.

Leader's span of control (SOC). To assess leader's span of control, we followed Schriesheim, Castro, and Yammarino (2000) and asked leaders "How many employees do you directly supervise?" We note that our conceptualization of span of control is different from that of group size, as a leader may have control over several groups. However, in our sample, span of control and group size are identical. 
Power distance orientation (PD). Employees rated their power distance orientation using a six-item scale developed by Dorfman and Howell (1988). Sample items are "I believe supervisors should rarely ask for the opinion of subordinates," and "I believe subordinates should not disagree with management decisions" $(\alpha=.71)$.

Organizational citizenship behaviors (OCB). Because our research setting is within the service industry wherein employee interactions with customers are important for organizational well-being, it was appropriate to examine helping behaviors directed at customers (OCB-C) in addition to those directed at the organization (OCB-O) (Bettencourt \& Brown, 1997). Accordingly, and because OCB-O and OCB-C were highly correlated $(r=.72)$, we used a tenitem measure to assess leader perceptions of employee OCBs directed at both the organization and customers (Bettencourt \& Brown, 1997; Moorman \& Blakely, 1995). Sample items are "This employee actively promotes the restaurant to potential customers," and "This employee voluntarily assists customers even if it means going beyond job requirements" $(\alpha=.94)$.

Control variables. Because we posit that ROQ will explain variance in outcomes of interest above and beyond perceptions of overqualification, we controlled for perceived overqualification. Furthermore, following theoretical and methodological considerations (Erdogan \& Liden, 2002; Podsakoff, MacKenzie, Paine, \& Bachrach, 2000) and meta-analytic findings (Ng \& Feldman, 2008; 2009; 2010), we controlled for employees' age, sex, education, and dyadic tenure. We measured dyadic tenure by asking employees how long they have been working with their current supervisor. It was important to control for dyadic tenure as research suggests that it could be influential in the quality of the supervisor-subordinate relationship (Maslyn \& Uhl-Bien, 2001). All analyses were run with and without controls to see if any 
significant differences were arising from the inclusion of control variables. Finding no such differences between the two sets of results, we report results from analyses with controls below.

\section{Analyses}

Because employees belonged to workgroups and group leaders rated citizenship behaviors of all members, we used multilevel (hierarchical) modeling techniques in Mplus 7 (Muthén \& Muthén, 2012) to test our hypotheses. Hierarchical modeling provides unbiased estimates by capturing the correlations among individual-level observations through the estimation of random effects (Hofmann, Griffin, \& Gavin, 2000). We used random-effects models in all analyses and group mean-centered independent variable (in this case, ROQ had been already centered), as well as the level-two moderator (i.e., span of control, and grand meancentered the group-level variable. We used Monte Carlo resampling method in Mplus to estimate 95\% confidence intervals (CIs) to test the mediated effect in Hypothesis 2. Similarly, to test the moderated mediation hypothesis (Hypothesis 5), we used Monte Carlo resampling method. The use of such CIs is superior to traditional methods in examining conditional indirect relationships because it ameliorates power problems introduced by non-normal sampling distributions of an indirect effect (Preacher, Zyphur, \& Zhang, 2010). To assess the models' goodness of fit, we obtained information on variance and residual variance of our variables in Mplus and calculated pseudo- $\mathrm{R}^{2}$ statistics using Snijders and Bosker's (1999) formula to measure the total amount of variance in the outcome variable explained by the predictors.

\section{Results}

Table 1 presents means, standard deviations, Cronbach's alpha reliabilities, and correlations among study variables. Prior to hypothesis testing, we conducted confirmatory factor analyses (CFA) to assess the psychometric properties of study measures rated by 
employees: POQ, LMXSC, and PD. Each item was constrained to fall under a single factor, and the factors were allowed to correlate. The three-factor model showed acceptable fit statistics, $\chi^{2}$ $(101)=251.63, p=.00, \mathrm{RMSEA}=.06, \mathrm{CFI}=.93, \mathrm{TLI}=.92$. To make comparisons, we ran alternate models with fewer factors. The CFA results showed that the hypothesized three-factor model had a superior fit with the data compared to the two-factor models where POQ and LMXSC were combined $\left(\Delta \chi^{2}(2)=465.25, p=.00\right)$, POQ and PD were combined $\left(\Delta \chi^{2}(2)=\right.$ 457.47, $p=.00)$, and LMXSC and PD were combined $\left(\Delta \chi^{2}(2)=226.57, p=.00\right)$. Likewise, the hypothesized three-factor model showed a superior fit with the data compared to the one-factor model where POQ, LMXSC, and PD were combined $\left(\Delta \chi^{2}(3)=681.00, p=.00\right)$.

To assess the incremental variance explained by ROQ beyond perceived overqualification and other control variables across our models, we created a preliminary model consisting of perceived overqualification along with employee age, sex, education, and dyadic tenure as a base model to be compared with our hypothesized models. Results of multilevel modeling showed that after controlling for the effects of perceived overqualification, group mean perceived overqualification, and other control variables, ROQ was positively related to employee LMXSC ( $\gamma=0.18, p=.03$ ), providing support for Hypothesis 1 (see Model 2, Table 2). Change in Pseudo $R^{2}$ revealed that ROQ explained significant incremental variance in LMXSC ( $\triangle$ Pseudo $\left.R^{2}=.05\right)$. In testing Hypothesis 2 , results of Monte Carlo resampling showed that after statistically controlling for the effects of perceived overqualification, group mean perceived overqualification, and other control variables, LMXSC significantly mediated the relationship between ROQ and OCBs ( $\beta=0.04$, bias-corrected 95\% CI [0.01, 0.08]), supporting Hypothesis 2 (see Table 3). 
In testing Hypothesis 3, results of the moderation analysis revealed that after controlling for the main effect of leader's span of control, and the effects of perceived overqualification, group mean perceived overqualification, and other control variables, leader's span of control weakened the ROQ-LMXSC relationship $(\gamma=-0.12, p=.01)$, providing support for Hypothesis 3 (see Model 4, Table 2). Change in Pseudo $R^{2}$ demonstrated that the interaction effect explained significant incremental variance in the outcome variable $\left(\Delta\right.$ Pseudo $\left.R^{2}=.03\right)$. Simple slope analysis (Aiken \& West, 1991) indicated that the nature of the interaction effect was consistent with our expectation (see Figure 2a), such that when leader's span of control was narrow (i. e., one standard deviation below mean), ROQ was more positively related to $\operatorname{LMXSC}(\gamma=0.37, t=$ $16.55, p=.00)$ than when leader's span of control was wide $(\gamma=0.13, t=2.84, p=.01)$.

In testing Hypothesis 4, results showed that after controlling for perceived overqualification, group mean perceived overqualification, other control variables, and the main effect of power distance orientation, there was a significant interaction between ROQ and power distance orientation in predicting LMXSC $(\gamma=0.22, p=.04)$, providing support for Hypothesis 4 (see Model 6, Table 2). Change in Pseudo $R^{2}$ revealed that the interaction effect explained significant incremental variance in the outcome $\left(\Delta\right.$ Pseudo $\left.R^{2}=.06\right)$. Consistent with our prediction (see Figure 2b), simple slope analysis showed that when power distance orientation was high (i.e., one standard deviation above mean), ROQ was positively and significantly related to $\operatorname{LMXSC}(\gamma=0.36, t=7.86, p=.00)$ whereas when power distance orientation was low, ROQ was not significantly related to $\operatorname{LMXSC}(\gamma=-0.01, t=-0.18, p=.86)$.

In testing the moderated mediation model proposed in Hypothesis 5, the results of Monte Carlo resampling revealed that the indirect ROQ-OCB link via LMXSC was stronger when span of control was low (unstandardized indirect effect $=0.07$, bias-corrected 95\% CI $[0.06,0.08]$ ) 
than when it was high (unstandardized indirect effect $=0.03$, bias-corrected $95 \%$ CI $[0.02$, 0.05]), supporting Hypothesis 5a (moderated mediation index $=0.04$, bias-corrected 95\% CI $[0.01,0.07]$, see Table 4). Next, results of Monte Carlo resampling method revealed that the indirect ROQ-OCB link via LMXSC was positive and significant when power distance orientation was high (unstandardized indirect effect $=0.06$, bias-corrected 95\% CI [0.05, 0.08]), whereas non-significant when power distance orientation was low (unstandardized indirect effect $=-0.01$, bias-corrected 95\% CI [-0.02, 0.02]), supporting Hypothesis $5 \mathrm{~b}$ (moderated mediation index $=0.07$, bias-corrected $95 \%$ CI $[0.03,0.11]$, see Table 4). Finally, we ran a model that included both interaction effects (Model 7, Table 2). Results showed that after controlling for the effects of perceived overqualification, group mean perceived overqualification, other control variables, and the main effect of ROQ, the interaction effect of leader's span of control and ROQ and the interaction effect of power distance orientation and ROQ were both significant $(\gamma=$ $0.11, p=.02 ; \gamma=0.23, p=.03$, respectively).

\section{Discussion}

To encompass employees' membership in workgroups, we extended the extant individual-centric overqualification research to a meso- and group-level model of overqualification. We integrated social comparison theory with social exchange theory to explicate the underlying mechanism and account for the effect of contextual factors in the relationship between employees' relative overqualification and citizenship behaviors. Our research showed that owing to within-group social comparison, employees' relative overqualification has a unique effect on employees' cognition and behavior above and beyond the effects of perceived overqualification. Further, this relative overqualification-organizational citizenship behaviors relationship was mediated by employees' relative standing with their 
leaders compared to other existing leader-follower relationships in the workgroup (i.e., LMXSC). Furthermore, we examined workgroup and individual attributes as contextual factors affecting the relationships among ROQ, LMXSC, and OCB. We found that both workgroup capacity and opportunity to invest in the relationships (measured as leaders' span of control) and individual orientation and investment in the relationships (measured as employees' power distance orientation) influenced the ROQ-LMXSC and ROQ-LMXSC-OCB relationships.

Our conceptualization of relative overqualification makes important theoretical contributions to the overqualification literature. To account for employees' embeddedness in workgroups, we drew on social comparison theory to propose an essential refinement in the prescriptions drawn solely on social exchange theory. Our refinement to individual level relationships arises from both meso (individual-within-a-workgroup) and group (cross level of workgroup on individuals) level considerations. In so doing, we attempted to address scholars' call for examining the social context of perceived overqualification in the workplace (Bashshur, Hernández, \& Peiró, 2011; Erdogan et al., 2011). Given the rise of workgroups as fundamental work units within organizations and the recognition that humans innately and continually engage in social comparisons, we deem social comparison theory important in developing more comprehensive and accurate models of overqualification. Our findings also have important theoretical implications for LMXSC literature. We drew linkages between overqualification research and leader-employee literature, especially in a workgroup context where a web of leader-follower relationships exists. We highlight how one's relative overqualification prompts employees' relative standing with leaders, and thus identify relative overqualification as an antecedent to LMXSC. 
Our theoretical model accounted for the possible effects of workgroup structure and individual normative attributes on the strength of the relationship between relative overqualification, LMXSC, and OCB. Negative cross-level effect of leader span of control and positive individual-level effect of employee power distance showed that ROQ-LMXSC and ROQ-LMXSC-OCB relationships are not universalistic, rather partly dependent on the contextual attributes. Our analyses revealed that wide span of control weakens and employee power distance orientation strengths the relationships between relative overqualification and its associates.

Our findings suggest that some of the mixed or weak findings in the extant overqualification research could be likely attributable to unaccounted workgroup membership and/or overlooked contextual factors surrounding the proposed relationship. Previous research has revealed overqualification to be both dysfunctional (e.g., decreased motivation and increased turnover intention: Simon, Bauer, Erdogan, \& Shepherd, 2019) and functional (e.g., increased proactive behaviors: Zhang et al., 2016). These studies, however, did not account for employee membership in workgroups and failed to include the workgroup context in research models. We built on Sierra's (2011) and Harari et al.'s (2017) call to account for the social context of overqualification, and we hope that our study stimulates additional research in this area.

Our findings also have important implications for social comparison theory. Because there are reasons not to expect just one (or only a few) employee to be overqualified in a workgroup, it is meaningful to use relative overqualification as a variable capable of explaining key outcome variables. Social comparisons among coworkers are unavoidable and relative overqualification allows us to account for that. Our findings demonstrate that relative overqualification has implications for how leader-member exchange is distributed among 
employees in the workgroup. Specifically, even though we did not directly or explicitly measure the ongoing social comparisons among employees, we showed that within-group relative overqualification status (a consequence of social comparison) associates with individuals' perceptions of leader-member exchange quality distribution in the workgroup. Furthermore, we show that employees' relative overqualification indirectly relates to their citizenship behaviors via the perception of leader-member exchange social comparison. It is noteworthy that relative overqualification is related to employees' perceptions and behaviors, beyond the effect of perceived overqualification. Hence, the results supported our expectation that perceived overqualification shapes a focal employee's perceptions and behaviors if there exists enough difference between the focal employee and the workgroup on overqualification. For instance, overqualified employees in workgroups wherein the majority of employees are overqualified may not find their job qualifications as distinctive to the organization as those in workgroups where overqualification is rare. In the former situation, perceived overqualification may not translate into expectations of being differentially treated and thereby does not contribute to organizational citizenship behaviors as employees do not find themselves distinct from their coworkers.

\section{Limitations and Future Directions}

Our study suffers from a few notable limitations. First, the concurrent measurement of study variables limits our ability to ascertain the direction of causality. Even though we developed theory-based arguments to establish the direction of the relationships, a possibility of alternative causal direction remains. For example, relatively overqualified employees could engage in higher levels of citizenship behaviors, resulting in higher levels of LMXSC. Our research design did not allow us to test this and other alternative models. Future studies applying 
longitudinal or experimental designs are warranted to establish causality and rule out the possibility of reverse causality among the variables of interest. Relatedly, our research design did not allow for testing or controlling for temporal effects, as overqualified employees may at some point undertake an effort to ingratiate themselves to the leader via organizational citizenship behaviors. We join Erdogan and Bauer (2021) to suggest that future research may examine how employee perceptions of overqualification change over time. This change could be as a response to changes in work design, leadership, and team context, or as a result of employee ingratiation and self-promotion.

Second, we acknowledge limitations in establishing a direct connection between the theoretical foundation of our study and our methods to measure relative overqualification. Even though our relative overqualification measure mirrored the method adopted by researchers in other research streams (e.g., Henderson, Wayne, Shore, Bommer, \& Tetrick, 2008; Vidyarthi et al., 2016), we did not explicitly measure employees' cognition of social comparisons. Our methodological approach in relative overqualification estimation is a proxy, rather than a direct measure, of the social comparison process. We recommend future research to develop new and unqualified measures of perceptual relative overqualification that shall account for within-group social comparison in a manner similar to that of the measure for relative leader-member exchange standing (LMXSC).

Third, aligned with the social comparison literature, we suggested that members who are embedded in the workgroup constitute relevant referents for employees' reactions to overqualification (Margolis \& Dust, 2019), and accordingly, we operationalized relative overqualification as the difference between an employee's perceived overqualification and the group mean of perceived overqualification. Nonetheless, we call for follow-up studies that 
explore whether employees may select other targets (e.g., a subgroup or a specific individual) for their social comparison processes and if they do, how it changes the relative overqualification dynamics suggested in this paper. For example, Li, Liao, and Han (in press) examined employees' perceptions of being more highly qualified than a particular coworker as a predictor of knowledge sharing with that coworker, suggesting that relative overqualification could have dyadic implications. Furthermore, our study focused merely on employees' perceptions of overqualification. Although the extant literature has justified the advantage of perceptual operationalization of overqualification in examining behavioral outcomes (Maltarich et al., 2011), differential mechanisms in regards with objective overqualification may exist that change the nature of our proposed relationships. Hence, we recommend that future studies replicate our analyses using objective measures of overqualification to examine whether results are similar.

Future research is recommended to not only overcome the limitations of the current study but also advance overqualification research in exciting and useful directions. Since Hawthorne studies (Roethlisberger \& Dickson, 1939), groups literature has established that groups influence individual members. However, these effects on specific aspects of management such as overqualification are yet to be fully explored. For example, overqualification researchers should investigate overqualification dynamics at the group level (e.g., Sierra, 2011) in future studies. Adopting multilevel approaches to overqualification would help us understand the implications of the overqualification composition of groups and the organizational-level implications on employees. One such question is how workgroups fare in group-level outcomes such as team performance or team potency when the average magnitude (i.e., group mean of overqualification) and distribution in individual overqualification (i.e., overqualification variation within the workgroup) differ among workgroups. Our conceptualization of relative 
overqualification can be an important step in that direction. Future research can integrate overqualification with other theories, such as social identity theory (Tajfel \& Turner, 1986) and job demands-resources (JD-R) theory (Demerouti, Bakker, Nachreiner, \& Schaufeli, 2001) to develop more nuanced models of overqualification. One extension of overqualification research may be to employ JD-R theory to view overqualification as a resource or as a demand. Overqualification-as-a-resource view, for instance, may be especially important in industries where job demands are high. Likewise future research may employ social identity theory to explain how the effects of social comparison is likely amplified such as when qualification is the primary identity of a focal employee.

Future research should establish the generalizability of our findings across various industries (e.g., IT industry or academia) and cultures. Our choice of power distance as a key moderator is consistent with the idea that the level of authority differentiation within a team is consequential for LMX, social exchanges and reciprocity (Wang \& Hollenbeck, 2019). Future research could examine other culture dimensions such as collectivism. Finally, future research may examine implications of employee overqualification for coworkers, customers, and close organizational outsiders (e.g., employee spouse).

\section{Practical Implications}

In contemporary organizations, organizational citizenship behaviors may be as important as employee job performance. This is because job descriptions are rather incomplete and thereby no longer form the only basis of assessment in many work practices. Hence, it is critical that managers know and actualize the conditions that make employees practice organizational citizenship behaviors rather than only focus on enhancing their job performance. Our findings suggest that overqualified employees, especially when placed in workgroups with narrow 
leader's span of control, engage in more citizenship behaviors as their relative within-group standing with their leader becomes superior. Leaders therefore must note that employees evaluate their overqualification with respect to the rest of the workgroup, and this relative evaluation associates with employees' standing with their leader compared to the coworkers' standing, which in turn shapes the citizenship potential of these employees. Leaders must pay close attention to these within-group social comparisons so employee citizenship behaviors can be maximized. We note that employee perceptions may not necessarily reflect reality, so leaders may be able to motivate subordinates by letting them know of their actual high standing in the overqualification distribution of workgroup, or by dropping hints about their high standing. Leaders may also change the span of control to optimize the influence that employee evaluations of relative overqualification have on their attitudes and behaviors. Leaders also need to understand the employees' power distance orientation, as it is a key driver of members' attitudes and behaviors. Findings of this study show that overqualified employees perceive higher relative standing with their leaders under the condition of high power distance orientation. In a diverse workforce, it is key for leaders to recognize employees' values and customize the leadership style appropriately.

Our findings have important implications for employees. One such implication is that overqualification is not always undesirable (van Dijk, Shantz, \& Alfes, 2020). Highly relatively overqualified employees can leverage their qualifications by establishing a high leader-member exchange compared to that of others, and consequently engage in more desirable behaviors (i.e., OCBs). This is even more likely for employees who have high power distance orientation. On the other hand, low relatively overqualified employees may have alternative ways of establishing relationships such as putting effort toward relationship development (Dulebohn et al., 2012). 
At the organizational level, human resource managers responsible for structural design need to consider the effects of leaders' span of control and employees' power distance so employee overqualification can be translated to organizational citizenship behaviors. Employee overqualification is hard to avoid, as organizations may be constrained in providing perfect roles to all employees. Even when the job role is a good fit, an employee may feel overqualified because of the overall workgroup makeup in terms of key skills and abilities. Thus, we recommend that organizations be structured with appropriate workgroup sizes to engender employee perceptions of a narrow span of control, which may facilitate high organizational citizenship behaviors. If a task or project merits a large team, then team leaders must be trained to give one-on-one attention to all members so the deleterious effects of a high span of control are reduced. Organizations may also train leaders to create an informal level of hierarchy within their teams, so employees feel they are part of smaller workgroups. Leaders should also go through cross-cultural training to understand employees' orientation of cultural norms.

\section{Conclusion}

Our study has important implications for overqualification research. Overqualification is not simply an individual-level phenomenon; instead, the social context of the workgroup has extensive influence. Our research confirms both the presence and effect of within-group social comparison alongside social exchanges in how overqualified employees form cognition of important work relationships and engage in citizenship behavior. Supported by the study results, we assert that viewing employees' overqualification in isolation may represent a partial (or even an erroneous) picture, and accounting for employees' social and individual context is imperative in theorizing and managerial practices concerning overqualification. Our findings suggest numerous theoretical, methodological, and practical directions for future research. 


\section{References}

Aiken, L. S., \& West, S. G. (1991). Multiple regression: Testing and interpreting interactions. London: Sage.

Allen, J., \& Van der Velden, R. (2001). Educational mismatches versus skill mismatches: effects on wages, job satisfaction, and on-the-job search. Oxford Economic Papers, 53, 434-452.

Anand, S., Hu, J., Liden, R.C., \& Vidyarthi, P.R. (2011). Leader-member exchange: Recent research findings and prospects for the future. In A. Bryman, D. Collinson, K. Grint, B. Jackson, \& M. Uhl-Bien (Eds.), The Sage handbook of leadership (pp. 311-325). Thousand Oaks, CA: Sage.

Anand, S., Vidyarthi, P., \& Rolnicki, S. (2018). Leader-member exchange and organizational citizenship behaviors: Contextual effects of leader power distance and group task interdependence. The Leadership Quarterly, 29, 489-500.

Antonakis, J., \& Atwater, L. (2002). Leader distance: A review and a proposed theory. The Leadership Quarterly, 13, 673-704.

Bashshur, M. R., Hernández, A., \& Peiró, J. M. (2011). The impact of underemployment on individual and team performance. In Underemployment (pp. 187-213). New York: Springer.

Berger, J., Cohen, B. P., \& Zelditch, M. (1972). Status conceptions and social interaction. American Sociological Review, 37, 241-255.

Bettencourt, L. A., \& Brown, S. W. (1997). Contact employees: Relationships among workplace fairness, job satisfaction, and prosocial service behaviors. Journal of Retailing, 73, 39-61.

Blau, P. M. (1964). Exchange and power in social life. New York: John Wiley \& Sons.

Blau, P. M., \& Schoenherr, R. A. (1971). The structure of organizations. New York: Basic Books.

Brislin, R.W. (1980). Translation and content analysis of oral and written materials. In H. C. Triandis, \& J. W. Berry (Eds.), Handbook of cross-cultural psychology (pp. 389-444). Boston, MA: Allyn \& Bacon.

Buunk, A. P., \& Gibbons, F. X. (2007). Social comparison: The end of a theory and the emergence of a field. Organizational Behavior and Human Decision Processes, 102, 321.

Chen, C., Smith, P., \& Mustard, C. (2010). The prevalence of over-qualification and its association with health status among occupationally active new immigrants to Canada. Ethnicity \& Health, 15, 601-619.

Cropanzano, R., \& Mitchell, M. S. (2005). Social exchange theory: An interdisciplinary review. Journal of Management, 31, 874-900.

Dansereau, F., Graen, G., \& Haga, W. J. (1975). A vertical dyad linkage approach to leadership within formal organizations: A longitudinal investigation of the role making process. Organizational Behavior and Human Performance, 13, 46-78.

Deng, H., Guan, Y., Wu, C. H., Erdogan, B., Bauer, T., \& Yao, X. (2018). A relational model of perceived overqualification: The moderating role of interpersonal influence on social acceptance. Journal of Management, 44, 3288-3310.

Demerouti, E., Bakker, A. B., Nachreiner, F., \& Schaufeli, W. B. (2001). The job demandsresources model of burnout. Journal of Applied Psychology, 86, 499-512.

Dienesch, R. M., \& Liden, R. C. (1986). Leader-member exchange model of leadership: A critique and further development. Academy of Management Review, 11, 618-634. 
Dorfman, P. W., \& Howell, J. P. (1988). Dimensions of national culture and effective leadership patterns: Hofstede revisited. Advances in International Comparative Management, 3, 127-150.

Dulebohn, J. H., Bommer, W. H., Liden, R. C., Brouer, R. L., \& Ferris, G. R. (2012). A metaanalysis of antecedents and consequences of leader-member exchange: Integrating the past with an eye toward the future. Journal of Management, 38, 1715-1759.

Edwards, J. R. (1995). Alternatives to difference scores as dependent variables in the study of congruence in organizational research. Organizational Behavior and Human Decision Processes, 64, 307-324.

Epitropaki, O., \& Martin, R. (2013). Transformational-transactional leadership and upward influence: The role of relative leader-member exchanges (RLMX) and perceived organizational support (POS). The Leadership Quarterly, 24, 299-315.

Erdogan, B. (2002). Leader-member exchange differentiation fairness: Evidence for a new construct. Retrieved from Dissertation Abstracts International. (UMI No. AAT 3058101)

Erdogan, B., \& Bauer, T. N. (2009). Perceived overqualification and its outcomes: The moderating role of empowerment. Journal of Applied Psychology, 94, 557-565.

Erdogan, B., \& Bauer, T. N. (2021). Overqualification at work: A review and synthesis of the literature. Annual Review of Organizational Psychology and Organizational Behavior, 8, 259-283.

Erdogan, B., Bauer, T. N., Peiró, J., \& Truxillo, D. M. (2011). Overqualified employees: Making the best of a potentially bad situation for individuals and organizations. Industrial and Organizational Psychology, 4, 215-232.

Erdogan, B., Karaeminogullari, A., Bauer, T. N., \& Ellis, A. M. (2020). Perceived overqualification at work: Implications for extra-role behaviors and advice network centrality. Journal of Management, 46, 583-606.

Erdogan, B., \& Liden, R. C. (2002). Social exchanges in the workplace. In L. L. Neider \& C. A. Schriesheim (Eds.), Leadership (pp. 65-114). Greenwich, CT: Information Age.

Festinger, L. (1954). A theory of social comparison processes. Human Relations, 7, 117-140.

Gilbert, D. T., Giesler, R. B., \& Morris, D. A. (1995). When comparisons arise. Journal of Personality and Social Psychology, 69, 227-236.

Greenberg, J., Ashton-James, C. E., \& Ashkanasy, N. M. (2007). Social comparison processes in organizations. Organizational Behavior and Human Decision Processes, 102, 22-41.

Gouldner, A. W. (1960). The norm of reciprocity: A preliminary statement. American Sociological Review, 25, 161-178.

Graen, G. (1976). Role-making processes within complex organizations. In M. D. Dunnette (Ed.). Handbook of industrial and organizational psychology (pp. 1201-1245). Chicago, IL: Rand McNally.

Graen, G. B., \& Scandura, T. A. (1987). Toward a psychology of dyadic organizing. In L. L. Cummings \& B. M. Staw (Eds.). Research in organizational behavior (pp. 175-208). Greenwich, CT: JAI Press.

Hackman, J. R. (2002). Leading teams: Setting the stage for great performances. Boston: Harvard Business School Press.

Han, J. H., Liao, H., Han, J., \& Li, A. N. (in press). When leader-member differentiation improves group functioning: The combined roles of differentiation bases and reward interdependence. Personnel Psychology. DOI: 10.1111/peps.12415. 
Harari, M. B., Manapragada, A., \& Viswesvaran, C. (2017). Who thinks they're a big fish in a small pond and why does it matter? A meta-analysis of perceived overqualification. Journal of Vocational Behavior, 102, 28-47.

Harris, T. B., Li, N., \& Kirkman, B. L. (2014). Leader-member exchange (LMX) in context: How LMX differentiation and LMX relational separation attenuate LMX's influence on OCB and turnover intention. The Leadership Quarterly, 25, 314-328.

Henderson, D. J., Liden, R. C., Glibkowski, B. C., \& Chaudhry, A. (2009). LMX differentiation: A multilevel review and examination of its antecedents and outcomes. The Leadership Quarterly, 20, 517-534.

Henderson, D. J., Wayne, S. J., Shore, L. M., Bommer, W. H., \& Tetrick, L. E. (2008). Leadermember exchange, differentiation and psychological contract fulfillment: A multilevel examination. Journal of Applied Psychology, 93, 1208-1219.

Ho, V. T. (2005). Social influence on evaluations of psychological contract fulfillment. Academy of Management Review, 30, 113-128.

Hofmann, D. A., Griffin, M. A., \& Gavin, M. B. (2000). The application of hierarchical linear modeling to organizational research. In K. J. Klein \& S. W. J. Kozlowski (Eds.), Multilevel theory, research, and methods in organizations: Foundations, extensions, and new directions (pp. 467-511). San Francisco, CA, US: Jossey-Bass.

Hofstede, G. (2001). Culture's consequences: Comparing values, behaviors, institutions, and organizations across nations. Thousand Oaks, CA: Sage.

Hu, J., Erdogan, B., Bauer, T. N., Jiang, K., Liu, S., \& Li, Y. (2015). There are lots of big fish in this pond: The role of peer overqualification on task significance, perceived fit, and performance for overqualified employees. Journal of Applied Psychology, 100, 12281238.

Hu, J. I. A., \& Liden, R. C. (2013). Relative leader-member exchange within team contexts: How and when social comparison impacts individual effectiveness. Personnel Psychology, 66, 127-172.

Javidan, M., Dorfman, P. W., de Luque, M. S., \& House, R. J. (2006). In the eye of the beholder: Cross-cultural lessons in leadership from Project GLOBE. Academy of Management Perspectives, 20, 67-90.

Johnson, G. J., \& Johnson, W. R. (1996). Perceived overqualification and psychological wellbeing. The Journal of Social Psychology, 136, 435-445.

Johnson, G. J., \& Johnson, W. R. (2000). Perceived overqualification and dimensions of job satisfaction: A longitudinal analysis. The Journal of Psychology, 134, 537-555.

Johnson, W. R., Morrow, P. C., \& Johnson, G. J. (2002). An evaluation of a perceived overqualification scale across work settings. The Journal of Psychology, 136, 425-441.

Kirkman, B. L., Chen, G., Farh, J. L., Chen, Z. X., \& Lowe, K. B. (2009). Individual power distance orientation and follower reactions to transformational leaders: A cross-level, cross-cultural examination. Academy of Management Journal, 52, 744-764.

Klein, K.J., Dansereau, F., \& Hall, R.J. (1994). Levels issues in theory development, data collection, and analysis. Academy of Management Review, 19, 195-229.

Kozlowski, S. W. J., \& Klein, K. J. (2000). A multilevel approach to theory and research in organizations: Contextual, temporal, and emergent processes. In K. J. Klein \& S. W. J. Kozlowski (Eds.), Multilevel theory, research, and methods in organizations: Foundations, extensions, and new directions (pp. 3-90). San Francisco: Jossey-Bass. 
Kristof-Brown, A. L., Zimmerman, R. D., \& Johnson, E. D. (2005). Consequences of individuals' fit at work: A meta-analysis of person-job, person-organization, persongroup, and person-supervisor fit. Personnel Psychology, 58, 281-342.

Li, C. S., Liao, H., \& Han, Y. (in press). I despise but also envy you: A dyadic investigation of perceived overqualification, perceived relative qualification, and knowledge hiding. Personnel Psychology, DOI: 10.1111/peps.12444.

Liden, R. C., Anand, S., \& Vidyarthi, P. (2016). Dyadic relationships. Annual Review of Organizational Psychology and Organizational Behavior, 3, 139-166.

Liden, R. C., Sparrowe, R. T., \& Wayne, S. J. (1997). Leader-member exchange theory: The past and potential for the future. Research in Personnel and Human Resources Management, 15, 47-120.

Lin, B., Law, K. S., \& Zhou, J. (2017). Why is underemployment related to creativity and OCB? A task-crafting explanation of the curvilinear moderated relations. Academy of Management Journal, 60, 156-177.

Liu, S., \& Wang, M. (2012). Perceived overqualification: A review and recommendations for research and practice. Research in Occupational Stress and Well-Being, 10, 1-42.

Maltarich, M. A., Reilly, G., \& Nyberg, A. J. (2011). Objective and subjective overqualification: Distinctions, relationships, and a place for each in the literature. Industrial and Organizational Psychology, 4, 236-239.

Margolis, J. A., \& Dust, S. B. (2019). It's all relative: A team-based social comparison model for self-evaluations of effectiveness. Group \& Organization Management, 44, 361-395.

Martin, R., Guillaume, Y., Thomas, G., Lee, A., \& Epitropaki, O. (2016). Leader-member exchange (LMX) and performance: A meta-analytic review. Personnel Psychology, 69, 67-121.

Maslyn, J. M., \& Uhl-Bien, M. (2001). Leader-member exchange and its dimensions: Effects of self-effort and other's effort on relationship quality. Journal of Applied Psychology, 86, 697-708.

Maynard, D. C., \& Parfyonova, N. M. (2013). Perceived overqualification and withdrawal behaviours: Examining the roles of job attitudes and work values. Journal of Occupational and Organizational Psychology, 86, 435-455.

Meyer, R. M., O'Brien-Pallas, L., Doran, D., Streiner, D., Ferguson-Pare, M., \& Duffield, C. (2011). Front-line leaders as boundary spanners: effects of span and time on nurse supervision satisfaction. Journal of Nursing Management, 19, 611-622.

Moorman, R. H., \& Blakely, G. L. (1995). Individualism-collectivism as an individual difference predictor of organizational citizenship behavior. Journal of Organizational Behavior, 16, 127-142.

Morgeson, F. P., DeRue, D. S., \& Karam, E. P. (2010). Leadership in teams: A functional approach to understanding leadership structures and processes. Journal of Management, 36, 5-39.

Muthén, L. K., \& Muthén, B. O. (2012). Mplus user's guide. (7th ed.). Los Angeles, CA: Muthén \& Muthén.

Ng, T. W., \& Feldman, D. C. (2008). The relationship of age to ten dimensions of job performance. Journal of Applied Psychology, 93, 392-423.

Ng, T. W., \& Feldman, D. C. (2009). How broadly does education contribute to job performance? Personnel Psychology, 62, 89-134. 
Ng, T. W., \& Feldman, D. C. (2010). Organizational tenure and job performance. Journal of Management, 36, 1220-1250.

Ouchi, W. G., \& Dowling, J. B. (1974). Defining the span of control. Administrative Science Quarterly, 19, 357-365.

Podsakoff, P. M., MacKenzie, S. B., Paine, J. B., \& Bachrach, D. G. (2000). Organizational citizenship behaviors: A critical review of the theoretical and empirical literature and suggestions for future research. Journal of Management, 26, 513-563.

Preacher, K. J., Zyphur, M. J., \& Zhang, Z. (2010). A general multilevel SEM framework for assessing multilevel mediation. Psychological Methods, 15, 209-233.

Reis, H. T., \& Sprecher, S. (Eds.). (2009). Encyclopedia of human relationships. Thousand Oaks, CA: SAGE.

Roethlisberger, F. J., \& Dickson, W. J. (1939). Management and the worker. Cambridge, MA: Harvard University Press.

Rose, S. J. (2017, February). Mismatch: How many workers with a Bachelor's degree are overqualified for their jobs? Retrieved from https://www.urban.org/sites/default/files/publication/87951/college_mismatch_final.pdf.

Schriesheim, C. A., Castro, S. L., \& Yammarino, F. J. (2000). Investigating contingencies: An examination of the impact of span of supervision and upward controllingness on leadermember exchange using traditional and multivariate within-and between-entities analysis. Journal of Applied Psychology, 85, 659-677.

Sierra, M. J. (2011). A multilevel approach to understanding employee overqualification. Industrial and Organizational Psychology, 4, 243-246.

Simon, H. A. (1957). Administrative behavior. New York: Free Press.

Simon, L. S., Bauer, T. N., Erdogan, B., \& Shepherd, W. (2019). Built to last: Interactive effects of perceived overqualification and proactive personality on new employee adjustment. Personnel Psychology, 72, 213-240.

Snijders, T., \& Bosker, R. (1999). Multilevel analysis: An introduction to basic and applied multilevel analysis. London: Sage.

Smith, K. K., \& Berg, D. N. (1987). Paradoxes of group life: Understanding conflict, paralysis, and movement in group dynamics. San Francisco: Jossey-Bass.

Sparrowe, R. T., \& Liden, R. C. (1997). Process and structure in leader-member exchange. Academy of Management Review, 22, 522-552.

Tajfel, H., \& Turner, J. (1986). The social identity theory of intergroup behavior. In S. Worchel \& W. G. Austin (Eds.), The social psychology of intergroup relations (pp. 7-24). Chicago: Nelson-Hall.

Timmerman, T. A. (2005). Missing persons in the study of groups. Journal of Organizational Behavior, 26, 21-36.

Tse, H. H. M., Ashkanasy, N. M., \& Dasborough, M. T. (2012). Relative leader-member exchange, negative affectivity and social identification: A moderated-mediation examination. The Leadership Quarterly, 23, 354-366.

van Dijk, H., Shantz, A., \& Alfes, K. (2020). Welcome to the bright side: Why, how, and when overqualification enhances performance. Human Resource Management Review, 30, 100688.

Vidyarthi, P. R., Liden, R. C., Anand, S., Erdogan, B., \& Ghosh, S. (2010). Where do I stand? Examining the effects of leader-member exchange social comparison on employee work behaviors. Journal of Applied Psychology, 95, 849-861. 
Vidyarthi, P. R., Singh, S., Erdogan, B., Chaudhry, A., Posthuma, R., \& Anand, S. (2016). Individual deals within teams: Investigating the role of relative i-deals for employee performance. Journal of Applied Psychology, 101, 1536-1552.

Wang, L. C., \& Hollenbeck, J. R. (2019). LMX in team-based contexts: TMX, authority differentiation, and skill differentiation as boundary conditions for leader reciprocation. Personnel Psychology, 72, 271-290.

Watson, W. E., Johnson, L., \& Merritt, D. (1998). Team orientation, self-orientation, and diversity in task groups: Their connection to team performance over time. Group \& Organization Management, 23, 161-188.

Williams, L. J., \& Anderson, S. E. (1991). Job satisfaction and organizational commitment as predictors of organizational citizenship and in-role behaviors. Journal of Management, 17, 601-617.

Wood, J. V. (1989). Theory and research concerning social comparisons of personal attributes. Psychological Bulletin, 106, 231-248.

Wood, J. V. (1996). What is social comparison and how should we study it? Personality and Social Psychology Bulletin, 22, 520-537.

Yang, J., Mossholder, K. W., \& Peng, T. K. (2007). Procedural justice climate and group power distance: An examination of cross-level interaction effects. Journal of Applied Psychology, 92, 681-692.

Zhang, M. J., Law, K. S., \& Lin, B. (2016). You think you are big fish in a small pond? Perceived overqualification, goal orientations, and proactivity at work. Journal of Organizational Behavior, 37, 61-84. 
Table 1

Descriptive Statistics, Intercorrelations, and Reliabilities for Individual-and Group-Level Variables

\begin{tabular}{|c|c|c|c|c|c|c|c|c|c|c|c|}
\hline Variables & $\mathrm{M}$ & SD & 1 & 2 & 3 & 4 & 5 & 6 & 7 & 8 & 9 \\
\hline 1. Age & 26.1 & 7.87 & & & & & & & & & \\
\hline 2. Sex & 0.63 & 0.49 & $-.24 * *$ & & & & & & & & \\
\hline 3. Education & 1.70 & 0.55 & -.10 & .02 & & & & & & & \\
\hline 4. Dyadic tenure & 1.71 & 2.32 & $.28 * *$ & $-.18 * *$ & $-.12 *$ & & & & & & \\
\hline 5. Perceived overqualification & 3.93 & 0.86 & .04 & -.04 & .11 & .10 & $(.86)$ & & & & \\
\hline 6. Power distance & 2.99 & 0.73 & .10 & -.11 & -.13 & .00 & .01 & $(.71)$ & & & \\
\hline 7. Relative overqualification & 0.00 & 0.69 & .09 & .03 & .05 & .03 & $.69 * *$ & -.01 & & & \\
\hline 8. LMXSC & 2.94 & 1.02 & .06 & -.10 & .04 & .12 & .03 & -.02 & $.15^{*}$ & $(.90)$ & \\
\hline 9. OCB & 4.10 & 0.87 & -.05 & -.08 & -.01 & .05 & .09 & $.15^{*}$ & .07 & $.19^{* *}$ & $(.94)$ \\
\hline \multicolumn{12}{|l|}{ Group level variables } \\
\hline 1. Span of control & 6.75 & 3.45 & & & & & & & & & \\
\hline 2. GOQ & 3.89 & 0.53 & .15 & & & & & & & & \\
\hline
\end{tabular}

Notes: individual level $n=243$; group level $n=36$; Cronbach's alpha reliabilities are reported along the diagonal. Age and dyadic tenure were in years. Sex was coded as $0=$ male, $1=$ female. Education was coded as $1=$ non-college degree, $2=$ undergraduate college degree, $3=$ graduate college degree. Relative overqualification is operationalized as the difference between an employee's perceived overqualification and the group mean of perceived overqualification; LMXSC is leader-member exchange social comparison. OCB is organizational citizenship behaviors. GOQ is group mean of perceive overqualification.

$* p<.05 . * * p<.01$. (two-tailed tests). 
Table 2

Multilevel Modeling Results for Relationships among ROQ, SOC, PD, and LMXSC

\begin{tabular}{|c|c|c|c|c|c|c|c|}
\hline \multirow[b]{2}{*}{ Variables } & \multicolumn{7}{|c|}{ LMXSC } \\
\hline & $\begin{array}{l}\text { Model } 1 \\
\text { estimates }\end{array}$ & $\begin{array}{c}\text { Model } 2 \\
\text { estimates } \\
(\mathrm{H} 1)\end{array}$ & $\begin{array}{l}\text { Model } 3 \\
\text { estimates }\end{array}$ & $\begin{array}{c}\text { Model } 4 \\
\text { estimates } \\
(\mathrm{H} 3)\end{array}$ & $\begin{array}{l}\text { Model } 5 \\
\text { estimates }\end{array}$ & $\begin{array}{c}\text { Model } 6 \\
\text { estimates } \\
(\mathrm{H} 4)\end{array}$ & $\begin{array}{c}\text { Model } 7 \\
\text { estimates }\end{array}$ \\
\hline Intercept, $\gamma_{00}$ & $0.01(0.09)$ & $0.01(0.10)$ & $0.03(0.08)$ & $0.03(0.08)$ & $0.01(0.10)$ & $-0.02(0.10)$ & $0.03(0.08)$ \\
\hline \multicolumn{8}{|l|}{ Control variables } \\
\hline Age, $\gamma_{10}$ & $0.01(0.01)$ & $0.01(0.01)$ & $0.01(0.01)$ & $0.01(0.01)$ & $0.01(0.01)$ & $0.01(0.01)$ & $0.01(0.01)$ \\
\hline Sex, $\gamma_{20}$ & $0.01(0.17)$ & $-0.02(0.17)$ & $-0.02(0.17)$ & $-0.02(0.17)$ & $-0.07(0.16)$ & $-0.01(0.16)$ & $0.01(0.16)$ \\
\hline Education, $\gamma_{30}$ & $-0.03(0.14)$ & $-0.04(0.14)$ & $-0.04(0.14)$ & $-0.04(0.12)$ & $-0.05(0.14)$ & $-0.01(0.14)$ & $0.01(0.13)$ \\
\hline Dyadic Tenure, $\gamma_{40}$ & $0.06(0.04)$ & $0.06(0.04)$ & $0.06(0.04)$ & $0.06(0.04)$ & $0.06(0.04)$ & $0.05(0.04)$ & $0.06(0.04)$ \\
\hline POQ, $\gamma_{50}$ & $0.11(0.09)$ & $0.13(0.09)$ & $0.13(0.09)$ & $0.15(0.09)$ & $0.13(0.09)$ & $0.19 *(0.08)$ & $0.17(0.08)$ \\
\hline GOQ, $\gamma_{01}$ & & $-0.18(0.12)$ & $-0.21(0.10)$ & $-0.20(0.10)$ & $-0.18(0.12)$ & $-0.18(0.12)$ & $-0.17(0.12)$ \\
\hline $\mathrm{ROQ}, \gamma_{60}$ & & $0.18 *(0.08)$ & $0.16^{*}(0.08)$ & $0.24 *(0.09)$ & $0.19 *(0.08)$ & $0.14 *(0.06)$ & $0.20 *(0.08)$ \\
\hline SOC, $\gamma_{02}$ & & & $-0.04(0.10)$ & $-0.04(0.10)$ & & & $-0.08(0.09)$ \\
\hline $\mathrm{ROQ} \times \mathrm{SOC}, \gamma_{62}$ & & & & $-0.12 *(0.04)$ & & & $-0.11 *(0.04)$ \\
\hline $\mathrm{PD}, \gamma_{70}$ & & & & & $0.10(0.09)$ & $0.02(0.09)$ & $0.06(0.09)$ \\
\hline $\mathrm{ROQ} \times \mathrm{PD}, \gamma_{80}$ & & & & & & $0.22 *(0.10)$ & $0.23 *(0.10)$ \\
\hline Pseudo $R^{2}$ & .01 & .06 & .06 & .09 & .06 & .12 & .15 \\
\hline$\Delta$ Pseudo $R^{2}$ & & .05 & & .03 & & .06 & \\
\hline
\end{tabular}

Notes: individual level $n=243$; group level $n=36$; Standard errors are represented in parentheses; LMXSC is leader-member exchange social comparison; POQ is perceived overqualification; GOQ is group mean of perceive overqualification; ROQ is relative overqualification

(operationalized as the difference between an employee's perceived overqualification and the group mean of perceived overqualification); SOC is leader's span of control; PD is power distance orientation; Pseudo $\mathrm{R}^{2}$ was calculated using the formula recommended by Snijders and Bosker (1999).

$* p<.05 . * * p<.01$. (two-tailed tests). 
Table 3

Results of Path Analysis

\begin{tabular}{|c|c|c|c|c|}
\hline \multirow{3}{*}{ Variables } & \multicolumn{4}{|c|}{ OCB } \\
\hline & \multicolumn{2}{|c|}{ Direct Effect } & \multicolumn{2}{|c|}{ Indirect Effect } \\
\hline & Estimate & $\begin{array}{c}\text { Bias-corrected } \\
95 \% \text { CI }\end{array}$ & Estimate & $\begin{array}{c}\text { Bias-corrected } \\
95 \% \text { CI }\end{array}$ \\
\hline Intercept & 4.09 & {$[3.35,4.82]$} & & \\
\hline Age & -0.01 & {$[-0.03,0.01]$} & & \\
\hline Sex & -0.11 & {$[-0.34,0.13]$} & & \\
\hline Education & -0.06 & {$[-0.27,0.14]$} & & \\
\hline Dyadic Tenure & -0.02 & {$[-0.14,0.09]$} & & \\
\hline POQ & 0.04 & {$[-0.13,0.21]$} & & \\
\hline GOQ & 0.09 & {$[-0.06,0.24]$} & & \\
\hline ROQ & 0.08 & {$[-0.08,0.25]$} & & \\
\hline LMXSC & 0.18 & {$[0.05,0.30]$} & & \\
\hline $\mathrm{ROQ} \rightarrow \mathrm{LMXSC} \rightarrow \mathrm{OCB}$ & & & 0.04 & {$[0.01,0.08]$} \\
\hline
\end{tabular}

Notes: individual level $n=243$; group level $n=36$; CI is confidence interval; POQ is perceived overqualification; GOQ is group mean of perceived overqualification; ROQ is relative overqualification (operationalized as the difference between an employee's perceived overqualification and the group mean of perceived overqualification); LMXSC is leader-member exchange social comparison; OCB is organizational citizenship behaviors. 
Table 4

Moderated Mediation Results for OCB across Levels of SOC and PD

\begin{tabular}{ccccc}
\hline Variable & Level & $\begin{array}{c}\text { Conditional } \\
\text { indirect effect }\end{array}$ & Lower 2.5\% & Upper 2.5\% \\
\hline ROQ $\rightarrow$ LMXSC $\rightarrow$ OCB & Low SOC & 0.07 & 0.06 & 0.08 \\
High SOC & 0.03 & 0.02 & 0.05 \\
& Difference & 0.04 & 0.01 & 0.07 \\
Low PD & -0.01 & -0.02 & 0.02 \\
High PD & 0.06 & 0.05 & 0.08 \\
Difference & 0.07 & 0.03 & 0.11 \\
\hline
\end{tabular}

Notes: individual level $n=243$; group level $n=36$; ROQ is relative overqualification (operationalized as the difference between an employee's perceived overqualification and the group mean of perceived overqualification); LMXSC is leader-member exchange social comparison; OCB is organizational citizenship behaviors; SOC is leader's span of control; PD is power distance orientation. 


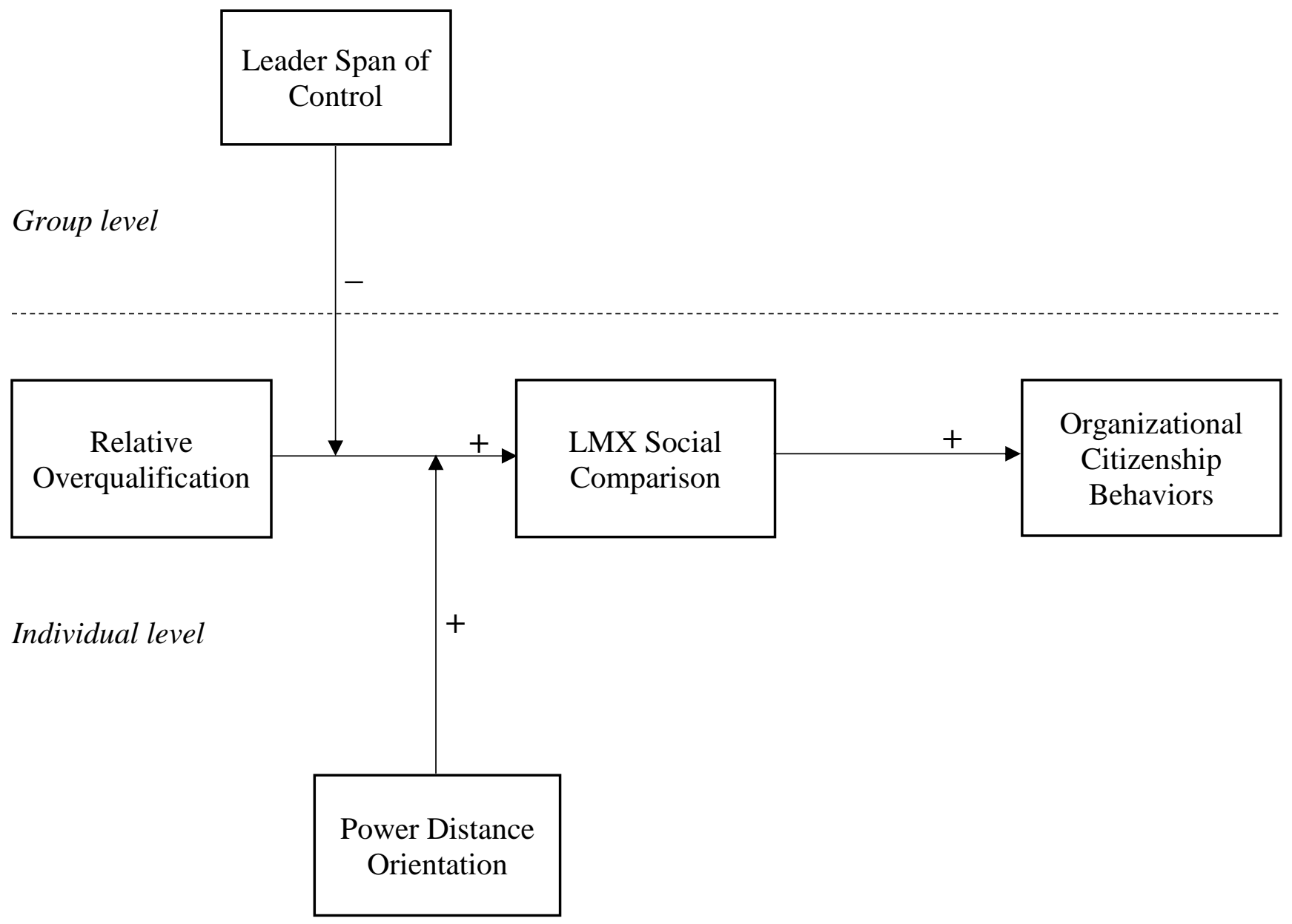

Figure 1. Research Model ${ }^{1}$

\footnotetext{
${ }^{1}$ Relative overqualification is operationalized as the difference between an employee's perceived overqualification and the group mean of perceived overqualification.
} 


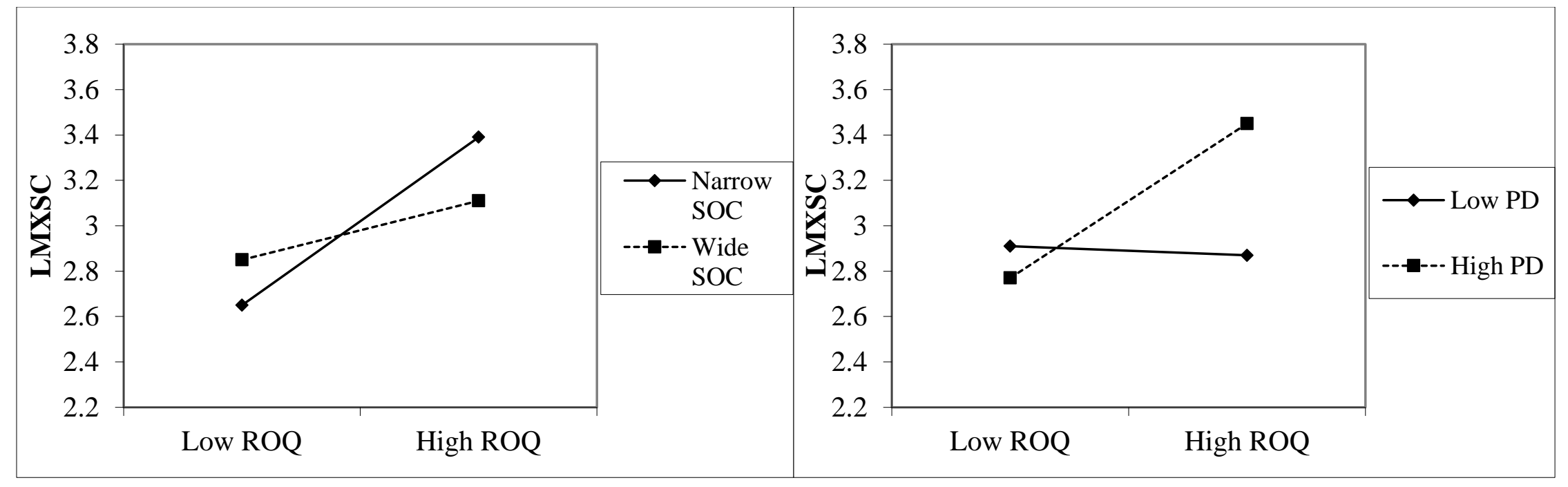

(a)

(b)

Figure 2. (a) Leader's Span of Control (SOC) as a Moderator of the ROQ-LMXSC Relationship, (b) Power Distance Orientation (PD) as a Moderator of the ROQ-LMXSC Relationship ${ }^{2}$

\footnotetext{
${ }^{2}$ Relative overqualification is operationalized as the difference between an employee's perceived overqualification and the group mean of perceived overqualification.
} 